Transfusion Medicine
and Hemotherapy
Review Article · Übersichtsarbeit

Transfus Med Hemother 2009;36:302-308

DOI: $\underline{10.1159 / 000235929}$
Received: July 21, 2009

Accepted: August 25,2009

Published online: September 10, 2009

\title{
Perspectives on Regulatory T Cell Therapies
}

\author{
Michael Probst-Kepper ${ }^{a} \quad$ Andrea Kröger ${ }^{b}$ Henk S.P. Garritsen ${ }^{c} \quad$ Jan Buer $^{d}$ \\ ${ }^{a}$ Institut für Mikrobiologie, Immunologie und Krankenhaushygiene, \\ ${ }^{\mathrm{b}}$ Institut für Klinische Transfusionsmedizin, Städtisches Klinikum Braunschweig gGmbH, \\ ${ }^{c}$ Molekulare Biotechnologie, Helmholtz Zentrum für Infektionsforschung, Braunschweig, \\ ${ }^{d}$ Institut für Medizinische Mikrobiologie, Universitätsklinikum Essen, Essen, Germany
}

\section{Key Words}

CD4+ CD25+ regulatory T cells · FOXP3 - GARP .

Positive feedback loop

\section{Summary}

Adoptive transfer in animal models clearly indicate an essential role of CD4+ CD25+ FOXP3+ regulatory $T\left(T_{\text {reg }}\right)$ cells in prevention and treatment of autoimmune and graft-versus-host disease. Thus, $\mathrm{T}_{\text {reg }}$ cell therapies and development of drugs that specifically enhance $T_{\text {reg }}$ cell function and development represent promising tools to establish dominant tolerance. So far, lack of specific markers to differentiate human $T_{\text {reg }}$ cells from activated CD4+ CD25+ effector T cells, which also express FOXP3 at different levels, hampered such an approach. Recent identification of the orphan receptor glycoprotein-A repetitions predominant (GARP or LRRC32) as $T_{\text {reg }}$ cell-specific key molecule that dominantly controls FOXP3 via a positive feedback loop opens up new perspectives for molecular and cellular therapies. This brief review focuses on the role of GARP as a safeguard of a complex regulatory network of human $\mathrm{T}_{\text {reg }}$ cells and its implications for regulatory $T$ cell therapies in autoimmunity and graft-versus-host disease.

\section{Introduction}

Negative selection in thymus does represent an imperfect process and thus self-reacting $\mathrm{T}$ cell clones do escape central tolerance. Therefore, to keep these potential dangerous self-

\author{
Schlüsselwörter \\ CD4+ CD25+ regulatorischen T-Zellen · FOXP3 - GARP . \\ Positiver "feedback loop"
}

\section{Zusammenfassung}

Tierexperimentelle Arbeiten zur adoptiven T-Zell-Therapie zeigten eindrücklich die bedeutende Funktion von CD4+ CD25+ FOXP3+ regulatorischen $T\left(T_{\text {reg }}\right)$-Zellen in der Prävention und Behandlung von Autoimmunkrankheiten und der Graft-versus-host-Erkrankung. Hierdurch stellt die Anwendung einer adoptiven $\mathrm{T}_{\text {reg-Zelltherapie }}$ bzw. die Entwicklung von Medikamenten, die die Funktion von $\mathrm{T}_{\text {reg }}$-Zellen spezifisch verstärken, eine neue Perspektive zur Etablierung einer dominanten Toleranz dar. Bisher wurde diese Entwicklung durch den Mangel spezifischer Oberflächenmarker zur sicheren Unterscheidung

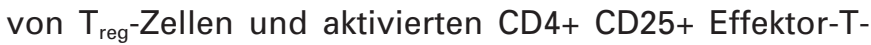
Zellen, die ebenfalls FOXP3 in unterschiedlichem Maße exprimieren, gehemmt. Die Entdeckung des Rezeptors "glycoprotein-A repetitions predominant" (GARP bzw. LRRC32) als $\mathrm{T}_{\text {reg }}$-Zell-spezifisches Schlüsselmolekül, das dominant FOXP3 in Verbindung mit einem positiven "feedback loop» kontrolliert, eröffnet neue Perspektiven für die zelluläre und molekulare $T_{\text {reg }}$-Zell-Therapie. Diese Übersicht befasst sich mit den Perspektiven, die die Entdeckung von GARP als "safeguard" eines komplexen regulatorischen Netzwerks humaner $\mathrm{T}_{\text {reg }}$-Zellen mit sich bringen, sowie mit deren Bedeutung für regulatorische T-Zell-Therapien bei Autoimmunkrankheiten and der Graft-versus-host-Erkrankung.

reactive $\mathrm{T}$ cells in check, a multitude of peripheral tolerance mechanisms exist. Dominant tolerance exerted by CD4+ regulatory $\mathrm{T}\left(\mathrm{T}_{\mathrm{reg}}\right)$ cells characterized by the expression of CD25 (IL2 receptor alpha) [1] does represent a major mechanism for immune homeostasis. A major breakthrough in the under-

\section{KARGER}

Fax +497614520714

Information@Karger.de

www.karger.com (c) 2009 S. Karger GmbH, Freiburg

Accessible online at:

www.karger.com/tmh 


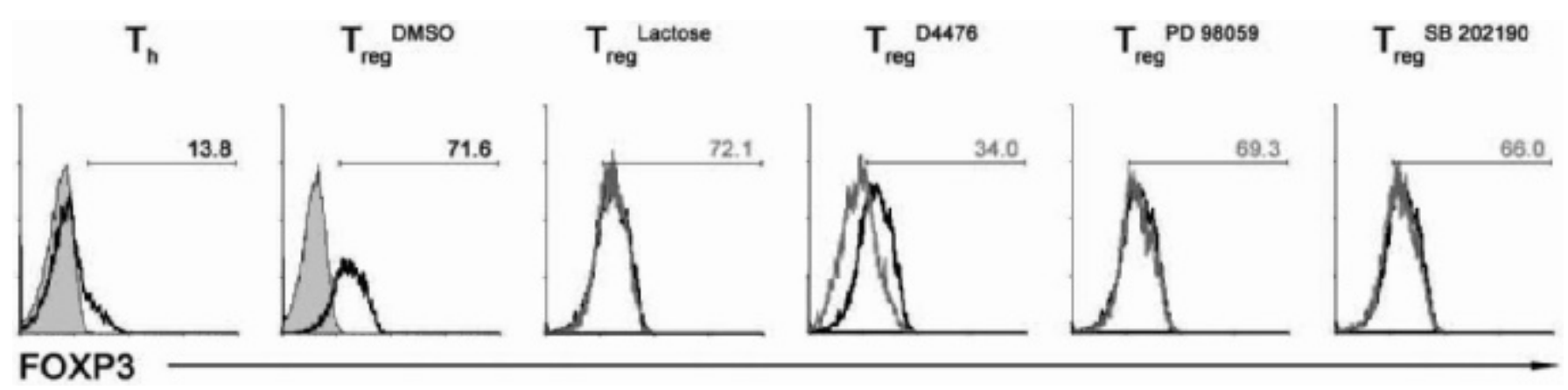

Fig. 1. CK1 inhibition affects FOXP3 expression in human $T_{\text {reg }}$ cells, suggesting the potential use of small molecules to interfere with $T_{\text {reg }}$ cell functions. Human alloantigen-specific $\mathrm{T}_{\text {reg }}$ cells were pretreated over night with lactose that impairs the lectin binding function of LGALS3 [11], CK1 kinase inhibitor (D4476, TOCRIS bioscience, Bristol, UK), and solvent control (DMSO) or irrelevant kinase inhibitors (PD98059 = MAP kinase inhibitor; SB202190 = p38 kinase inhibitor) and analyzed for intracellular FOXP3 as described [13].

standing of this peculiar subpopulation of CD4+ T cells was the identification of the forkhead transcription factor FOXP3 that is essential for their development and function [2-4]. The roles of FOXP3 and $\mathrm{T}_{\text {reg }}$ cells are compellingly demonstrated by the natural loss-of-function, leading to the development of a fatal autoimmune lymphoproliferative disorder in man (IPEX, immunodysregulation, polyendocrinopathy, and enteropathy, X-linked) and mice (scurfy) [5]. Despite advances since the identification of FOXP3 for understanding $\mathrm{T}_{\text {reg }}$ cell lineage, commitment and function differences between mice and man have become apparent [6]. Contrary to murine $\mathrm{T}_{\text {reg }}$ cells, which are expressing FOXP3 as lineage-specific marker, consensus has now been reached that $\mathrm{T}$ cell receptor (TCR) stimulation of human nonregulatory CD4+ CD25- $T_{h}$ cells does induce FOXP3 expression without interfering with the expression of effector cytokines like IL2 and IFN $\gamma$ or the acquisition of suppressor function [7-10]. Moreover, even antigen-specific $T_{h}$ lines and clones can express FOXP3 to different extends [11-15]. With that, FOXP3 does not represent a bona fide marker of human $\mathrm{T}_{\text {reg }}$ cells, suggesting the existence of a $\mathrm{T}_{\text {reg }}$ cell-specific marker and/or higher-order regulatory networks to explain the qualitative and quantitative differences of FOXP3 expression of human $\mathrm{T}_{\text {reg }}$ compared to conventional $\mathrm{T}_{\mathrm{h}}$ cells $[16,17]$.

\section{GARP Controls FOXP3 via a Positive Feedback Loop}

The question of $\mathrm{T}_{\text {reg }}$ cell-specific control mechanisms has been answered only recently with the identification of the orphan receptor glycoprotein-A repetitions predominant (GARP or LRRC32). GARP does represent a $T_{\text {reg }}$ cell-specific molecule that dominantly controls FOXP3 via a positive feedback loop (see below) $[13,18,19] . \mathrm{T}_{\text {reg }}$ cell-specific expression of GARP has been further confirmed at the DNA level with the identification of a hypomethylated region in intron 1 together with two differentially methylated regions with enhancer function in human $\mathrm{T}_{\text {reg }}$ cells [20]. Thus, lineage-directing transcription of GARP in $\mathrm{T}_{\text {reg }}$ cells is based most likely on differential accessibility of the locus similar to what has been described for FOXP3 [15, 21].

The identification of GARP was enabled by differential gene expression analysis of TCR stimulated CD4+ CD25+ $\mathrm{T}_{\text {reg }}$ cells compared to their CD4+ CD25- $\mathrm{T}_{\mathrm{h}}$ cell counterparts (www.ncbi.nlm.nih.gov/geo/query/acc.cgi?acc = GSE13017) as TCR stimulation represents the prerequisite to activate their mutually exclusive functions. The functional contribution of GARP to the genetic program and phenotype of $\mathrm{T}_{\text {reg }}$ cells was elucidated by ectopic overexpression in human alloantigen-specific $\mathrm{T}_{\mathrm{h}}$ cells and downregulation of GARP in human alloantigen-specific $\mathrm{T}_{\text {reg }}$ cells. Retroviral overexpression of GARP in $T_{h}$ cells led to an efficient and stable re-programming of effector $\mathrm{T}$ towards $\mathrm{T}_{\text {reg }}$ cells. This was associated with induction of constitutive expression of FOXP3, the $\beta$-galactoside binding protein LGALS3, the cystein-endoprotease LGMN, and an extended $\mathrm{T}_{\text {reg }}$ cell signature similar to $\mathrm{T}_{\text {reg }}$ cells [13]. Interestingly, LGALS3, recently identified FOXP3-dependent gene [11], and LGMN do represent minor constituents of this feedback loop as they enhance GARP and FOXP3 expression following TCR activation. LGALS represents an interesting regulator of anergy as it has been shown to directly interfere with TCR proximal signaling in human T cells [22]. Furthermore, FOXP3 induction via ectopic expression of LGALS3 depends on an intact serine-6 CK1 phosphorylation site [13], whereas kinase inhibition of CK1 in $\mathrm{T}_{\text {reg }}$ cells downregulates FOXP3 expression (fig. 1). The result of the GARP-dependent re-programming process is established only after some rounds of antigen-specific TCR-(re-)stimulation. Surprisingly, GARP was more efficient, and the regulatory phenotype induced was stable compared to the overexpression of FOXP3. The final outcome of this complex transcriptional re-programming/ transdifferentiation of effector $T_{h}$ cells towards $T_{\text {reg }}$ cells was obvious as most of the $\mathrm{T}_{\text {reg }}$ cell signature genes showed a sustained high level of expression and induction of effector cytokines was lost $[13,18]$. 


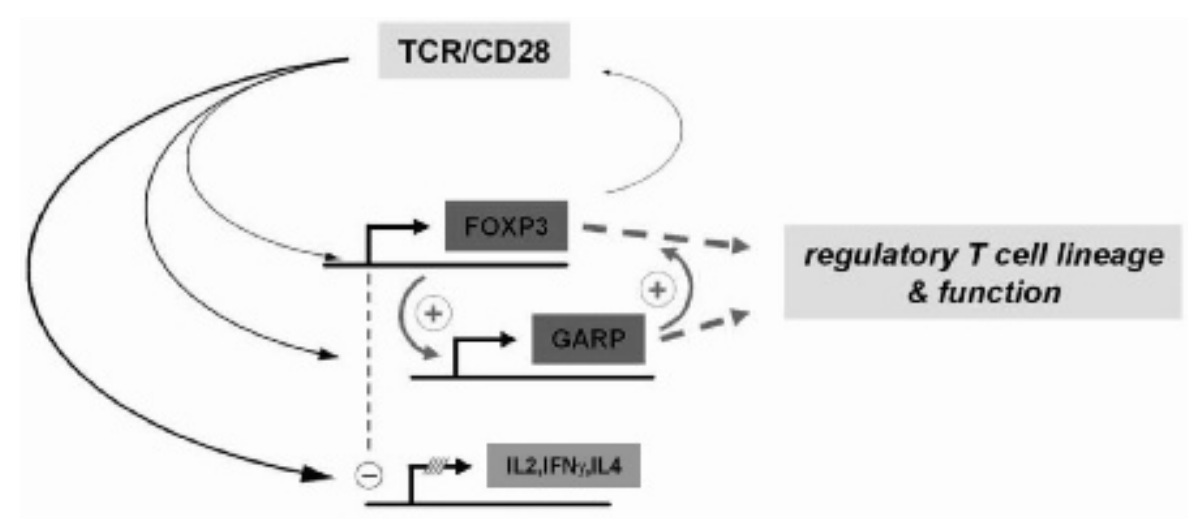

Fig. 2. GARP as safeguard of the regulatory phenotype. Qualitative and quantitative differences of FOXP3 expression between $T_{\text {reg }}$ (upper panel) and $\mathrm{T}_{\mathrm{h}}$ cells (lower panel) with their mutually exclusive effector and regulatory functions can be explained in part by the existence of $\mathrm{T}_{\mathrm{reg}}$-specific control mechanisms. First of all, FOXP3 is expressed ab initio in $\mathrm{T}_{\text {reg }}$ cells, because of difference in the accessibility of the FOXP3 locus [15, 21], whereas it is induced with delay in $\mathrm{T}_{h}$ cells following TCR stimulation. Lineage-restricted induction of GARP due also to selective hypomethylation of the locus in $\mathrm{T}_{\mathrm{reg}}$ cells [20] (indicated by lack of black dots) initiates a positive feedback loop that enhances and maintains high levels of FOXP3. This regulatory network is associated with redundant GARP/FOXP3-enhancing molecules, e.g. the $\beta$-galactoside-binding protein LGALS3, which also reveals lineagespecific differences of DNA methylation [20], the endoprotease LGMN, receptor CD27 and CD83 suggesting a higher-order regulatory network [13].

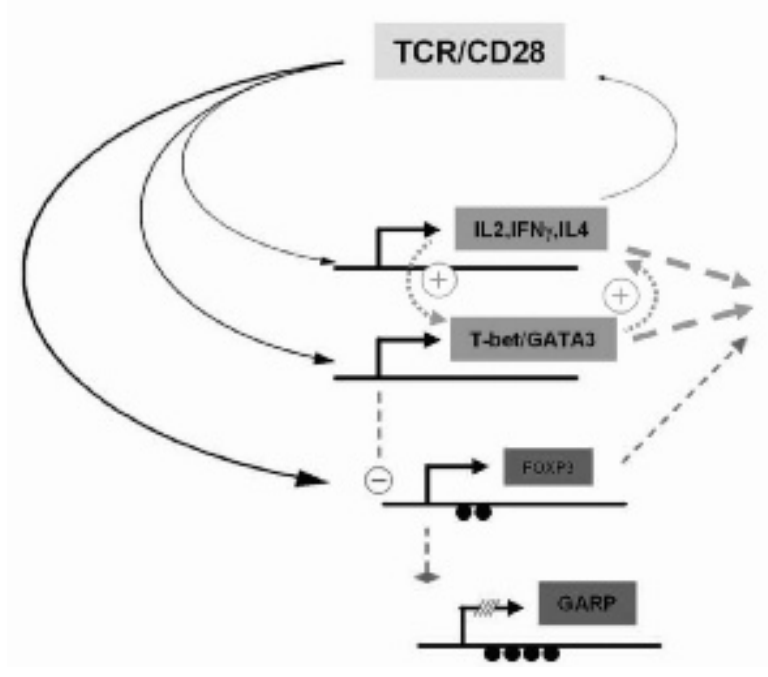

effector $T$ cell lineage \& function

Contrary, downregulation of GARP in human $\mathrm{T}_{\text {reg }}$ cells, achieved by lentiviral transduction of specific small interfering RNA (siRNA), significantly impaired suppressor function and FOXP3 expression. This was associated with impaired induction of $\mathrm{CD} 83$ and $\mathrm{CD} 27$, both representing known FOXP3-regulating receptors [13, 23, 24]. Strikingly, lentiviral downregulation of FOXP3 with specific siRNA in $\mathrm{T}_{\text {reg }}$ cells resulted in similar phenotypic changes and affected induction of GARP, CD83, and CD27. Therefore, a GARP-FOXP3positive feedback loop in human $\mathrm{T}_{\text {reg }}$ cells and a close interrelation with other FOXP3-regulating cell surface receptor systems was compellingly established. With that, speculations on a higher-order regulatory network and the necessity on a new molecular definition of human $\mathrm{T}_{\text {reg }}$ cells $[16,17]$ reached a robust conceptual framework (fig. 2). Moreover, as TGF $\beta$ induced $\mathrm{T}_{\text {reg }}$ cells do not upregulate GARP, lack of GARP might explain the only transient and partial phenotype of TGF $\beta 1$-induced regulatory $\mathrm{T}_{\mathrm{h}}$ cells [10], corroborating the need for a safeguard of FOXP3 expression and maintenance of the regulatory program. In sum, GARP is a key receptor controlling FOXP3 in $\mathrm{T}_{\text {reg }}$ cells following TCR activation in a positive feedback loop, representing a promising new system for the therapeutic manipulation of $\mathrm{T}$ cells in human immune diseases (fig. 3).

\section{Future Directions of $T_{\text {reg }}$ Cell Therapies in View of GARP}

Because of the encouraging results of adoptive transfer showing an essential role of CD4+ CD25+ FOXP3 $+\mathrm{T}_{\text {reg }}$ cells in prevention and treatment of autoimmune [25-27] and graftversus-host disease (GvHD) [28-30] in animal models, first clinical trials have been started with CD4+ CD25+ T cells in humans $[31,32]$. These trials should also provide insights into the potential effects of $\mathrm{T}_{\text {reg }}$ cell therapies on the graftversus-leukemia effect, which is linked in part to GvHD [33]. But keeping in mind the difficulties to achieve pure $T_{\text {reg }}$ cell 
Fig. 3. Adoptive $T_{\text {reg }}$ cell therapy - perspectives. Based on the isolation of either CD4+ CD25-/int/+ $\mathrm{T}_{\mathrm{h}}$ cells or $\mathrm{CD} 4+\mathrm{CD} 25^{\text {hi }}$ $\mathrm{T}_{\text {reg }}$ cells, two different strategies exist for adoptive regulatory T cell applications. i) Isolation of antigenspecific $\mathrm{CD} 4+\mathrm{T}_{\mathrm{h}}$ cells from different disease settings (e.g. GvHD or autoimmunity) with the use of 'classical' antigen-specific stimulation/cloning procedures or by tretramer/ multimer separation [15], and re-programming/transdifferentiation of these diseaseassociated effector towards $\mathrm{T}_{\text {reg }}$ cells via genetic engineering with GARP as described for alloantigen-specific $T_{h}$ cells [13]. ii) Isolation of $T_{\text {reg }}$ cells and their preferable antigen-specific expansions with the need for re-isolation to exclude potential harmful antigen-specific $\mathrm{T}_{\mathrm{h}}$ cells included in the preparation be means of $\mathrm{T}_{\text {reg }}$ cell-specific marker(s), including e.g. GARP or the recently described strategy of using CD121 (IL1R), recently identified as FOXP3-dependend molecule [11], and LAP as $\mathrm{T}_{\text {reg }}$ markers $[19,38,48]$ (table 1$)$.

preparations with using CD4+ CD25+ as surrogate marker of human $\mathrm{T}_{\text {reg }}$ cells [34], more reliable surface markers to exclude potential hazardous $T_{h}$ cell contaminations from $T_{\text {reg }}$ cell preparations have to be used. Such markers should be lineagespecific and indicators of proper regulatory function. GARP fulfills these demands as lineage-specific $\mathrm{T}_{\text {reg }}$ marker that is responsible for maintenance of the regulatory program (fig. 3 ). Concerning the limitations of $T_{\text {reg }}$ cell availability and the dominant role of GARP leading to stable FOXP3 expression and regulatory function in terminal differentiated alloantigenspecific $T_{h}$ cells [13], genetically engineering disease-associated $\mathrm{T}_{\mathrm{h}}$ cells would represent an attractive alternative (fig. 3).

\section{Clinical Application of $\mathbf{T}_{\text {reg }}$ Cells}

In order to facilitate the transformation of research-based cell cultures and processes into clinical good manufacturing practice (GMP) procedures which are required for clinical application, a number of hurdles have to be taken. A strict standardization of the production is one of the most important parameters. Minimizing risks of contamination, especially microbial contamination during the cultivation process, is another important prerequisite for clinical application. Therefore, the clinical acceptance will be greatly improved with cell-cultivating systems which are modular closed systems and easy to use.
As we described in the first part of this review, $\mathrm{T}_{\text {reg }}$ cells represent a critical component of the immune regulatory system. Through availability of specific antibodies and improved understanding of functional and genetic differentiation of $\mathrm{T}_{\text {reg }}$ cells, we are now able to better define these $\mathrm{T}$ cells and standardize their isolation and quality control (fig. 3). An important point still represents the limited quantity of $\mathrm{T}_{\text {reg }}$ cells, representing a rare subset of $\mathrm{CD} 4+\mathrm{T}$ cells estimated to be $2-4 \%$ or even lower, concerning proper gating to sort pure $\mathrm{T}_{\text {reg }}$ cells [35-37]. Thus, ex vivo expansion is necessary but hindered by the fact that $T_{\text {reg }}$ cells replicate slowly in comparison to conventional $T_{h}$ cells [38]. In other words, if a batch of $T_{\text {reg }}$ cells is contaminated with other $T_{h}$ cells, these will in the end overgrow the $\mathrm{T}_{\text {reg }}$ cell population, necessitating a re-purification step (fig. 3). This problem has been noticed with most surface markers of human $\mathrm{T}_{\text {reg }}$ cells (table 1 ). Therefore, combinations of separate markers for primary enrichment of $\mathrm{T}_{\text {reg }}$ cells ex vivo (e.g. CD4+ CD25+ CD127 ${ }^{\text {lo }}$ [39]) and later re-purification using other markers like GARP or other molecules differentially expressed on $T_{\text {reg }}$ cells (table 1 ) seems to be the future concept to get more pure $\mathrm{T}_{\text {reg }}$ preparations [38].

In the research situation most of the isolation procedures were performed using FACS sorting, a cell sorting methodology based upon physical properties of the cellular elements and use of fluorescently labelled antibodies against specific cellular membrane receptors [37], which is time consuming. Thus, Riley et al. [31] stated the cumbersome FACS isolation 
Table 1. Potential markers of human $\mathrm{T}_{\text {reg }}$ cells besides GARP

\begin{tabular}{|c|c|c|}
\hline Marker & Comment & Reference \\
\hline $\mathrm{CD} 25+$ & $\begin{array}{l}\text { not specific; no long-term stability of isolated cells* (if not sorted for CD } 25^{\text {hi }}[11] \text {; } \\
60-80 \% \text { FOXP3 + after MACS isolation [36]) }\end{array}$ & [34] \\
\hline CD152 & $\begin{array}{l}\text { ionomycine-stimulation needed, not specific; long-term stability of isolated cells } \\
\text { not determined }\end{array}$ & [49] \\
\hline MHC-class II & not specific; no long-term stability of isolated cells tested & {$[50]$} \\
\hline $\mathrm{CD} 127^{\mathrm{lo}}$ & not specific; no long-term stability of isolated cells* [38] & {$[51]$} \\
\hline $\mathrm{CD} 27+$ & not specific; long-term stability of isolated cells not determined & {$[48]$} \\
\hline CD39 & not specific; long-term stability of isolated cells not determined & {$[52]$} \\
\hline $\mathrm{CD} 121 \mathrm{a}+\mathrm{CD} 121 \mathrm{~b}+$ & $\begin{array}{l}\text { not specific, long-term stability of isolated cells not determined; improved purity of } \\
\text { CD25+CD127 }\end{array}$ & {$[38]$} \\
\hline $\mathrm{LAP}+$ & $\begin{array}{l}\text { not specific, long-term stability of isolated cells not determined; improved purity of } \\
\text { CD25+ CD } 127^{\text {lo }} \text { reported }(>90 \%) \text {; GARP represents receptor of latent TGF } \beta / \text { LAP [53] }\end{array}$ & {$[38]$} \\
\hline $\mathrm{CD} 83+$ & not specific, stimulation needed; long-term stability of isolated cells not determined & {$[13,23]$} \\
\hline $\mathrm{CD} 33^{\text {hi }}$ & not specific, stimulation needed; long-term stability of isolated cells not determined & {$[13]$} \\
\hline
\end{tabular}

of this infrequent cell type by the words 'take a billion or so and call me in the morning'. Yet there is another important point with respect to contamination. FACS sorting is a relative open system with numerous porte d'entrées for microorganisms. This problem gets even greater concerning the need for several separation steps for enrichment and re-purification of antigen-specific $\mathrm{T}_{\text {reg }}$ cells for cellular therapies, discussed above. In conclusion it will be difficult to obtain sufficient $T_{\text {reg }}$ cells under GMP conditions using this approach.

Modern cytapheresis procedures are the basis for harvesting sufficient numbers of mononuclear cells $\left(10^{10}-10^{11}\right)$ within an acceptable amount of time. This is not only possible for healthy donors but can be achieved with patients as well [4042]. The collected mononuclear cells are harvested under the same conditions as classical blood products such as thrombocytapheresis products and are suitable for further processing in GMP facilities.

Novel immunomagnetic techniques in combination with specific antibodies enable the rapid isolation of cells in cell culture bags. This approach enables isolation and cultivation of a large amount of $\mathrm{T}_{\text {reg }}$ cells in a GMP setting and therefore facilitates the clinical applicability of these cells [39, 43]. This approach also includes the possibility of ex vivo generation of human alloantigen-specific $\mathrm{T}_{\text {reg }}$ cells at the step of in vitro expansion by means of antigen-specific stimulation with the use of a primary enrichment and a second re-purification step including GARP and other potential markers of $\mathrm{T}_{\text {reg }}$ cells (table 1) [39]. Further protocols enable the ex vivo expansion of antigen-specific $T_{h}$ cells and genetic modifications of these cells $[13,44]$. Although attractive, these approaches however are still rarely found in clinical settings.

Other approaches result from the better understanding of the $\mathrm{T}_{\text {reg }}$ cells and try to modify $\mathrm{T}_{\text {reg }}$ cells responses pharmacologically, for example by using antibodies, cytokines, or small molecules [45] (fig. 1).
Combining the knowledge we have on $\mathrm{T}_{\text {reg }}$ cells with efficient medical devices for harvesting (apheresis) and isolation (e.g. clinimacs) we are gradually coming in a position in which we will see clinical applications starting.

\section{Concluding Remarks}

The identification of GARP as lineage-restricted key receptor of human $\mathrm{T}_{\text {reg }}$ cells and the characterization of a GARPFOXP3 positive feedback loop as essential component for the maintenance of the regulatory phenotype does provide a conceptual framework for a new molecular definition of the regulatory program. Open questions remaining include the signal transduction pathway of GARP and the potential ligand. Development of potential GARP-ligand mimetics to enhance regulatory functions in vivo should take into account expression and function of GARP in platelets [46, 47]. In-depth elucidation of the GARP-FOXP3 regulatory system does represent a major challenge for the future and opens up the possibility for generation of antigen-specific $T_{\text {reg }}$ cells for adoptive cellular therapies (fig. 3) and identification of new molecular targets to develop new strategies to enhance $\mathrm{T}_{\text {reg }}$ cells in autoimmune diseases and transplantation.

\section{Acknowledgments}

Michael Probst-Kepper was supported by grants of the VolkswagenStiftung and Deutsche Forschungsgemeinschaft.

\section{Disclosure}

The authors declared no conflict of interest. 


\section{References}

1 Sakaguchi S, Sakaguchi N, Asano M, Itoh M, Toda M: Immunologic self-tolerance maintained by activated $T$ cells expressing IL-2 receptor alpha-chains (CD25). Breakdown of a single mechanism of selftolerance causes various autoimmune diseases. J Immunol 1995;155:1151-1164.

2 Khattri R, Cox T, Yasayko SA, Ramsdell F: An essential role for Scurfin in CD4+CD25+ T regulatory cells. Nat Immunol 2003;4:337-342.

$\checkmark 3$ Fontenot JD, Gavin MA, Rudensky AY: Foxp3 programs the development and function of CD4+CD25+ regulatory T cells. Nat Immunol 2003;4: 330-336.

4 Hori S, Nomura T, Sakaguchi S: Control of regulatory $\mathrm{T}$ cell development by the transcription factor Foxp3. Science 2003;299:1057-1061.

$\checkmark 5$ Ochs HD, Ziegler SF, Torgerson TR: FOXP3 acts as a rheostat of the immune response. Immunol Rev 2005;203:156-164.

6 Ziegler SF: FOXP3: of mice and men. Annu Rev Immunol 2006;24:209-26.

7 Gavin MA, Torgerson TR, Houston E, deRoos P, Ho WY, Stray-Pedersen A, Ocheltree EL, Greenberg PD, Ochs HD, Rudensky AY: Single-cell analysis of normal and FOXP3-mutan human T cells: FOXP3 expression without regulatory T cell development. Proc Natl Acad Sci U S A 2006;103:6659-6664.

8 Allan SE, Crome SQ, Crellin NK, Passerini L, Steiner TS, Bacchetta R, Roncarolo MG, Levings MK: Activation-induced FOXP3 in human T effector cells does not suppress proliferation or cytokine production. Int Immunol 2007;19:345-354.

$\checkmark$ Wang F, Ioan-Facsinay A, van der Voort EIH, Huizinga TW, Toes RE: Transient expression of FOXP3 in human activated nonregulatory CD4+ T cells. Eur J Immunol 2007;37:129-138.

10 Tran DQ, Ramsey H, Shevach EM: Induction of FOXP3 expression in naive human CD4+FOXP3$\mathrm{T}$ cells by $\mathrm{T}$ cell receptor stimulation is TGF $\beta$-dependent but does not confer a regulatory phenotype. Blood 2007;110:2983-2990.

11 Ocklenburg F, Moharregh-Khiabani D, Geffers R, Janke V, Pfoertner S, Garritsen H, Groebe L, Klempnauer J, Dittmar KE, Weiss S, et al: UBD, a downstream element of FOXP3, allows the identification of LGALS3, a new marker of human regulatory T cells. Lab Invest 2006;86:724-737.

12 Probst-Kepper M: Conjunctival FOXP3 in trachoma: T cells not specified. PLoS Med 2006;3:e506.

13 Probst-Kepper M, Geffers R, Kröger A, Viegas N, Erck C, Hecht HJ, Lünsdorf H, Roubin R, Moharregh-Khiabani D, Wagner K, et al: GARP: a key receptor controlling FOXP3 in human regulatory T cells. J Cell Mol Med 2009;DOI: 10.1111/j.15824934.2009.00782.x

$>_{14} \frac{4}{\text { Stokis J, Fink W, Francois V, Connerotte T, de }}$ Smet C, Knoops L, van der Bruggen P, Coulie PG Lucas S: Comparison of stable human Treg and Th clones by transcriptional profiling. Eur J Immuno 2009;39:869-882.

15 Francois V, Ottaviani S, Renkvist N, Stockis J, Schuler G, Thielemans K, Colau D, Marchand M, Boon T, Lucas S, et al: The CD4+ T-cell response of melanoma patients to a MAGE-A3 peptide vaccine involves potential regulatory $\mathrm{T}$ cells. Cancer Res 2009;69:4335-4354.

16 Roncarolo MG, Gregori S: Is FOXP3 a bona fide marker for human regulatory T cells? Eur J Immunol 2008;38:925-927.

17 Hori S: Rethinking the molecular definition of regulatory T cells. Eur J Immunol 2008;38:901-937.
18 Wang R, Wan Q, Kozhaya L, Fujii H, Unutmaz $\mathrm{D}$ : Identification of a regulatory $\mathrm{T}$ cell specific cell surface molecule that mediates suppressive signals and induces Foxp3 expression. PLoS ONE 2008;3: e27705.

19 Tran DQ, Shevach EM: Therapeutic potential of FOXP3 regulatory $\mathrm{T}$ cells and their interactions with dendritic cells. Hum Immunol 2009;70:294-299.

20 Schmidl C, Klug M, Boeld TJ, Andreesen R, Hoffmann P, Edinger M, Rehli M: Lineage-specific DNA methylation in T cells correlates with histone methylation and enhancer activity. Genome Res 2009;19:1165-1174.

21 Floess S, Freyer J, Siewert C, Baron U, Olek S, Polansky J, Schlawe K, Chang HD, Bopp T, Schmitt E, et al: Epigenetic control of the foxp3 locus in regulatory T cells. PLoS Biol 2007;5:e38.

22 Demotte N, Stroobant V, Van Der Smissen P, Colau D, Luescher EF, Hivroz C, Nicaise C, Squifflet J, Mourad M, Godelaine D, et al: Restoring the association of the $\mathrm{T}$ cell receptor with $\mathrm{CD} 8$ reverses anergy in human tumor-infiltrating lymphocytes. Immunity 2008;28:414-424.

23 Reinwald S, Wiethe C, Westendorf AM, Breloer M, Probst-Kepper M, Fleischer B, Steinkasserer A, Buer J, Hansen W: CD83 expression in CD4+ T cells modulates inflammation and autoimmunity. $\mathrm{J}$ Immunol 2008;180:5890-5897.

24 Yang ZZ, Novak AJ, Ziesmer SC, Witzig TE, Ansell SM: CD70+ non-Hodgkin lymphoma B cells induce Foxp3 expression and regulatory function in intratumoral CD4+CD25 $\mathrm{T}$ cells. Blood 2008; 110:2537-2544.

25 Tang Q, Henriksen KJ, Bi M, Finger EB, Szot G, Ye J, Masteller EL, McDevitt H, Bonyhadi M, Bluestone JA: In vitro-expanded antigen-specific regulatory $\mathrm{T}$ cells suppress autoimmune diabetes. J Exp Med 2004;199:1455-1465.

26 Mukherjee R, Chaturvedi P, Qin HY, Singh B: $\mathrm{CD} 4+\mathrm{CD} 25+$ regulatory $\mathrm{T}$ cells generated in response to insulin B:9-23 peptide prevent adoptive transfer of diabetes by diabetogenic T cells. J Autoimmun 2003;21:221-237.

27 Tarbell KV, Yamazaki S, Olson K, Toy P, Steinman RM. CD25+ CD4+ T cells, expanded with dendritic cells presenting a single autoantigenic peptide, suppress autoimmune diabetes. J Exp Med 2004;199:1467-1477.

$\checkmark 28$ Cohen JL, Trenado A, Vasey D, Klatzmann D, Salomon BL: CD4+CD25+ immunoregulatory T cells: new therapeutics for graft-versus-host disease. J Exp Med 2002;196:401-406.

29 Taylor PA, Lees CJ, Blazar BR: The infusion of ex vivo activated and expanded CD4+CD25+ immune regulatory cells inhibits graft-versus-host disease lethality. Blood 2002;99:3493-3499.

30 Nishimura E, Sakihama T, Setoguchi R, Tanaka $\mathrm{K}$, Sakaguchi S: Induction of antigen-specific immunologic tolerance by in vivo and in vitro antigen-specific expansion of naturally arising Foxp3+CD25+CD4+ regulatory T cells. Int Immunol 2004;16:1189-1201.

31 Riley JL, June CH, Blazar BR: Human T regulatory cell therapy: take a billion or so and call me in the morning. Immunity 2009;30:656-665.

32 Reed W, Noga SJ, Gee AP, Rooney CM, Wagner JE, McCullough J, McKenna DH, Whiteside TL, Donnenberg AD, Baker AK, et al: Production Assistance for Cellular Therapies (PCAT): five-year experience from the United States National Heart, Lung, and Blood Institute (NHLBI) contract research program in cell and tissue therapies. Transfusion 2009;49:786-796.
3 Rezvani AR, Storb RF: Separation of graft-vs.tumor effects from graft-vs.-host disease in allogeneic hematopoietic cell transplatation. J Autoimmun 2008;30:172-179.

34 Allan SE, Broady R, Gregori S, Himmel ME, Locke N, Roncarolo MG, Bacchetta R, Levings MK: CD4+ T-regulatory cells: toward therapy for human diseases. Immunol Rev 2008;223:391-421.

35 Seddiki N, Santner-Nanan B, Tangye SG, Alexander Sl, Solomon M, Lee S, Nanan R, Fazekas de Saint Groth B: Persistence of naive CD45RA+ regulatory T cells in adult life. Blood 2006;107:2830 2838

36 Pfoertner S, Jeron A, Probst-Kepper M, Guzman CA, Hansen W, Westendorf AM, Toepfer T, Schrader AJ, Franzke A, Buer J, et al: Signatures of human regulatory $\mathrm{T}$ Cells: an encounter with old friends and new players. Genome Biol 2006;7:R541-R54-18.

37 Trzonkowski P, Szaryñska M, Mysliwska J, Mysliwski A: Ex vivo expansion of CD4(+)CD25(+) T regulatory cells for immunosuppressive therapy. Cytometry 2009;75:175-188.

38 Tran DQ, Andersson J, Hardwick D, Bebris L, Illei GG, Shevach EM: Selective expression of latencyassociated peptide (LAP) and IL-1 receptor type I/ II (CD121a/CD121b) on activated human FOXP3+ regulatory $\mathrm{T}$ cells allows for their purification from expansion cultures. Blood 2009;113:5125-5133.

39 Peters JH, Preijers FW, Woestenenk R, Hilbrands LB, Koenen HJPM, Joosten I: Clinical grade Treg: GMP isolation, improvement of purity by $\mathrm{CD} 127^{\text {pos }}$ depletion, Treg expansion, and Treg cryopreservation. PLoS ONE 2009;3:e3161.

40 Thurner B, Röder C, Dieckmann D, Heuer M, Kruse M, Keikavoussi P, Kämpgen E, Bender A, Schuler G: Generation of large numbers of fully mature and stable dendritic cells from leukapheresis products for clinical application. J Immunol Methods 1999;223:1-15.

41 Strasser EF, Berger TG, Weisbach V, Zimmermann R, Ringwald J, Schuler-Thurner B, Zingsem $\mathrm{J}$, Eckstein R: Comparison of two apheresis systems for the collection of CD14+ cells intended to be used in dendritic cell culture. Transfusion 2003;43: 1309-1316.

42 Wolf C, Meyer M, Riggert J: Leukapheresis for the extraction of monocytes and various lymphocyte subpopulations from peripheral blood: product quality and prediction of the yield using different harvest procedures. Vox Sang 2005;249-255.

43 Hoffmann P, Boeld TJ, Eder R, Albrecht J, Doser K, Biserka P, Dada A, Niemand C, Assenmacher $\mathrm{M}$, Orso E, et al: Isolation of CD4+CD25+ regulatory $\mathrm{T}$ cells for clinical trials. Biol Blood Marrow Transplant 2006;12:267-274.

44 Allan SE, Alstad AN, Merindol N, Crellin NK, Amendola M, Bacchetta R, Naldini L, Roncarolo MG, Soudeyns H, Levings MK: Generation of potent and stable human CD4+ T regulatory cells by activation-independent expression of FOXP3. Mol Ther 2008;16:194-202.

45 Bruno L, Merkenschlager M: Directing T cell differentiation and function with small molecule in hibitors. Cell Cycle 2009;7:2296-2298.

46 Macaulay IC, Tijssen MR, Thijssen-Timmer DC, Gusnanto A, Steward M, Burns P, Langford CF, Ellis $\mathrm{P}$, Dudbridge $\mathrm{F}$, Zwaginga JJ, et al: Comparative gene expression profiling of in vitro differentiated megakaryocytes and erythroblasts identifies novel activatory and inhibitory platelet membrane proteins. Blood 2006;109:3260-3269. 
47 O'Connor N, Salles I, Cvejic A, Watkins NA, Walker A, Garner S, Macaulay IC, Steward M, Zwaginga J, Bray S, et al: Functional genomics in zebrafish permits rapid characterization of novel platelet membrane proteins. Blood 2008;113:4754-5762.

48 Koenen HJPM, Fasse E, Joosten I: CD27/CFSEbased ex vivo selection of highly suppressive alloantigen-specific human regulatory T cells. J Immunol 2005;174:7573-7583.

49 Birebent B, Lorho R, Lechartier H, de Guibert S, Alizadeh M, Vu N, Beauplet A, Robillard N, Semana G: Suppressive properties of human CD4+CD25+ regulatory $\mathrm{T}$ cells are dependent on CTLA-4 expression. Eur J Immunol 2004;34:3485-3496.
50 Baecher-Allan C, Wolf E, Hafler DA: MHC class II expression identifies functionally distinct human regulatory T cells. J Immunol 2006;176:4622-4631. 51 Liu W, Putnam AL, Xu-yu Z, Szot GL, Lee MR, Zhu S, Gottlieb PA, Kapranov P, Gingeras TR, de St.Groth BF, et al: CD127 expression inversely correlates with FoxP3 and suppressive function of human CD4+ T reg cells. J Exp Med 2006;203:1701-1711.

52 Borsellino G, Kleinewietfeld M, Di Mitri D, Sternjak A, Diamantini A, Giometto R, Hopner S, Centonze D, Bernardi G, Dell'acqua ML, et al: Expression of ectonucleotidase CD39 by Foxp3+ Treg cells: hydrolysis of extracellular ATP and immune suppression. Blood 2007;110:1225-1232.
53 Tran DQ, Andersson J, Wang R, Ramsey H, Unutmaz D, Shevach EM: GARP (LRRC32) is essential for the surface expression of latent TGF-(beta) on platelets and activated FOXP3+ regulatory $\mathrm{T}$ cells. Proc Natl Acad Sci U S A 2009; doi: 10.1073/ pnas.0901944106. 